\section{Avaliação da capacidade aeróbia determinada por respostas sanguíneas e ventilatórias em quatro diferentes ergômetros}

\author{
Assessment of aerobic capacity through blood and \\ ventilatory responses in four different ergometers
}

\author{
Alessandro Moura Zagatto \\ Marcelo Papoti ${ }^{2}$ \\ Ivan Masselli dos Reis ${ }^{3}$ \\ Wladimir Rafael Beck ${ }^{3}$ \\ Claudio Alexandre Gobatto ${ }^{3}$
}

Resumo - O objetivo do presente estudo foi comparar as intensidades do ponto de compensação respiratório (PCR), limiar anaeróbio de concentração fixa $\left(\mathrm{OBLA}_{3,5}\right)$ e limiar anaeróbio de lactato de aumento abrupto lactacidêmico $\left(\operatorname{LAn}_{\mathrm{LAC}}\right)$ determinadas em diferentes ergômetros. Para isso, onze mesatenistas ( $19 \pm 1$ anos) realizaram testes incrementais máximos no cicloergômetro, ergômetro de braço, esteira e em teste específico para o tênis de mesa. Durante esses esforços, foram mensuradas as repostas lactacidêmica e respiratória. $\mathrm{Na}$ análise intraergômetro, não foram encontradas diferenças significativas entre o PCR, $\mathrm{LAn}_{\mathrm{LAC}}$ e OBLA ${ }_{3,5}$ no ergômetro de braço $(63,4 \pm 4,8 \mathrm{~W}, 66,9 \pm 4,5 \mathrm{~W}$ e $64,5 \pm 6,1 \mathrm{~W}$, respectivamente), esteira $\left(11,4 \pm 0,4 \mathrm{~km} \cdot \mathrm{h}^{-1}, 11,3 \pm 0,3 \mathrm{~km} \cdot \mathrm{h}^{-1}\right.$ e $11,1 \pm 0,3 \mathrm{~km} \cdot \mathrm{h}^{-1}$, respectivamente) e teste específico $\left(40,5 \pm 1,8\right.$ bolas $\mathrm{min}^{-1}, 42,6 \pm 3,6$ bolas $\mathrm{min}^{-1}$ e $42,8 \pm 5,6$ bolas $\mathrm{min}^{-1}$, respectivamente); apenas no cicloergômetro foi verificado menor valor de OBLA $(131,9 \pm 6,6 \mathrm{~W})$ em relação ao PCR $(149,3 \pm 4,9 \mathrm{~W})$ e o $\operatorname{LAn}_{\mathrm{LAC}}(149,3 \pm 4,7 \mathrm{~W})$. No entanto, fortes e significativas correlações foram verificadas no teste específico entre todos esses métodos ( $\mathrm{r}$ entre 0,83 a 0,95 ), entre o PCR e $\mathrm{OBLA}_{3,5}$ no ergômetro de braço $(\mathrm{r}=0,78)$ e entre OBLA ${ }_{3,5}$ e LAn $_{\text {LAC }}$ na esteira $(r=0,76)$. Desse modo, podemos concluir que o PCR, OBLA $_{3,5}$ e LAn ${ }_{\text {LAC }}$ parecem corresponder ao mesmo fenômeno fisiológico, principalmente, no teste específico para o tênis de mesa.

Palavras-chave: Capacidade aeróbia; Ergometria; Lactato sanguíneo; Limiar anaeróbio; Ponto de compensação respiratório.

Abstract - The objective of the study was to compare intensities of respiratory compensation point $(R C P)$, anaerobic threshold at onset blood lactate accumulation $\left(O B L A_{3,5}\right)$, and anaerobic threshold at lactate abrupt increase $\left(A n T_{L A C}\right)$ determined in four different ergom-

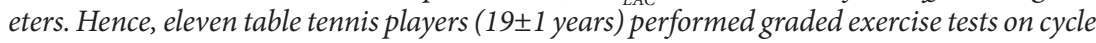
ergometer, arm cranking ergometer, treadmill and specific table tennis test. The respiratory response and lactatemia were measured during the tests. We did not find significant differences among $R C P, A n T_{L A C}$ and $O B L A_{3,5}$ in arm cranking ergometer $(63.4 \pm 4.8 \mathrm{~W}, 66.9 \pm 4.5 \mathrm{~W}$ and $64.5 \pm 6.1 \mathrm{~W}$, respectively), treadmill $\left(11.4 \pm 0.4 \mathrm{~km} \cdot \mathrm{h}^{-1}, 11.3 \pm 0.3 \mathrm{~km} \cdot \mathrm{h}^{-1}\right.$ and $11.1 \pm 0.3 \mathrm{~km} \cdot \mathrm{h}^{-1}$, respectively), and specific table tennis test $\left(40.5 \pm 1.8\right.$ bolas min $^{-1}, 42.6 \pm 3.6$ bolas min $^{-1}$ and $42.8 \pm 5.6$ bolas min ${ }^{-1}$, respectively). However, the $O B L A_{3,5}(131.9 \pm 6.6 \mathrm{~W})$ was significantly lower than $R C P(149.3 \pm 4.9 \mathrm{~W})$ and $A n T_{L A C}(149.3 \pm 4.7 \mathrm{~W})$ in the cycle ergometer. Strong and significant correlation coefficients were found in the specific test for all methods ( $r$ range 0.83 to 0.95$)$, in arm cranking ergometer between $R C P$ and $O B L A_{3,5}(r=0.78)$, and on treadmill running between $O B L A_{3,5}$ and $A n T_{L A C}(r=0.76)$. Therefore, we conclude that $R C P, O B L A_{3,5}$ and $A n T_{L A C}$ seem to correspond to the same physiological phenomenon, mostly during specific table tennis test.

Key words: Aerobic capacity; Anaerobic threshold; Blood lactate; Ergometry; Respiratory compensation point.
1 Universidade Estadual Paulista "Júlio de Mesquita Filho". Faculdade de Ciências. Departamento de Educação Física. Bauru, SP. Brasil

2 Universidade de São Paulo. Escola de Educação Física e Esporte. Laboratório de Fisiologia do Exercício. Ribeirão Preto, SP. Brasil.

3 Universidade Estadual de Campinas. Faculdade de Ciências Aplicadas. Laboratório de Fisiologia Aplicada ao Esporte. Limeira. SP. Brasil.

Recebido em 20/08/12 Revisado em 21/09/12 Aprovado em 23/11/12 


\section{INTRODUÇÃO}

A capacidade aeróbia corresponde a maior intensidade em que é verificado um equilíbrio entre a produção e remoção do lactato sanguíneo ${ }^{1,2}$ ou mesmo a intensidade em que ocorre um aumento abrupto da resposta lactacidêmica em relação ao exercício ${ }^{3}$ e tem sido considerada um importante fenômeno fisiológico na avaliação da aptidão aeróbia ${ }^{2,4}$ e prescrição da intensidade de exercício ${ }^{5,6}$.

O teste de máxima fase estável de lactato (MFEL) tem sido considerado o teste padrão ouro na determinação da capacidade aeróbia ${ }^{2}$ e essa intensidade apresenta ótima sensibilidade aos efeitos decorrentes do treinamento físico regular e sistemático, tornando seu uso muito mais atrativo em relação a utilização do consumo máximo de oxigênio $\left(\dot{V} O_{2 \max }\right)$ (índice de potência aeróbia máxima $)^{7,8}$. Contudo, esse grande atrativo pode ser ofuscado devido ao alto dispêndio de tempo necessário para sua aplicação, podendo levar vários dias para a realização das diversas sessões de exercício de cargas retangulares. Essa condição tem estimulado a realização de diversos estudos no intuito de desenvolver protocolos que estimem a intensidade de MFEL (iMFEL) em apenas uma sessão de exercício ${ }^{1,4,9,10}$,como o lactato mínimo $^{4,10}$, limiar anaeróbio ${ }^{1,11}$, limiar anaeróbio individual ${ }^{12}$ ou o ponto de compensação respiratório ${ }^{13-15}$, sendo esses os mais utilizados na ciência do esporte para avaliação e prescrição do exercício ${ }^{6,9,14-16}$.

No entanto, a determinação da capacidade aeróbia parecer ser influencia pelo tipo de ergômetro utilizado no teste, como demonstrado por Beneke e von Duvillard ${ }^{17}$, que mostraram que a concentração de lactato na MFEL é alterada conforme o modo de exercício. Essa alteração ocorre, principalmente, na resposta lactacidêmica, na intensidade da capacidade aeróbia, sendo essa menor quando o exercício é aplicado de um ergômetro que envolve maior massa muscular devido a uma maior capacidade de remoção de lactato por esse músculo ativo. Assim, como a resposta lactacidemia é alterada, outros procedimentos de avaliação da capacidade aeróbia também podem ser afetados por essa alteração, como o limiar anaeróbio de concentração fixa. Em adição a massa muscular envolvida no exercício, a especificidade do modo de exercício ao tipo de treinamento também é muito evidenciada, como descrito por Tordi et al. ${ }^{18}$, em que as adaptações ocorridas com o treinamento em um grupamento muscular não são totalmente transferidas aos grupos musculares não treinados. Esse fato foi verificado por Roels et al. ${ }^{16}$ quando compararam o $\mathrm{VO}_{2 \max }$ e capacidade aeróbia entre nadadores e triatletas, e verificaram maiores valores desses parâmetros nos nadadores, no teste em nado livre, enquanto que os valores nos triatletas foram maiores quando avaliados no cicloergômetro.

Além da seleção do modo de exercício ou ergômetro, a seleção do procedimento de avaliação da capacidade aeróbia também poderia apresentar resultados divergentes ${ }^{19}$, embora todos esses procedimentos sejam assumidos como procedimentos que avaliam o mesmo fenômeno fisiológico ${ }^{12,20}$.

No contexto prático, a escolha do ergômetro e do procedimento de avaliação da capacidade aeróbia é baseada na disponibilidade do ergômetro e do 
equipamento para mensuração da variável fisiológica. Assim, geralmente esses testes são aplicados em ergômetros convencionais, como o cicloergômetro e esteira, independente do esporte treinado, devido à facilidade de acesso a esses ergômetros, e a lactacidemia tem sido a variável mais utilizada nessa avaliação. Assim, essa análise poderia auxiliar na seleção de um procedimento rápido e preciso para a determinação da capacidade aeróbia, assim como o ergômetro mais adequado, minimizando os eventuais erros de medida nessa análise.

Até a presente data, nós não temos conhecimentos de estudos que comparam o efeito de diferentes modos de exercícios, tanto esforços de membro superior quanto inferior, entre exercício específico e o treinamento não específico, assim como diferentes métodos de determinação da capacidade aeróbia em teste incremental no mesmo trabalho. Essa análise no mesmo estudo possibilitaria uma interpretação mais robusta desse possível efeito.

Desse modo, principal problema foi verificar se: existe diferença entre o modo de exercício na determinação de capacidade aeróbia estimada por diferentes métodos em um teste incremental, assim como é verificado no teste de MFEL; e isso é influenciado pelo procedimento de determinação utilizado? Assim, o objetivo do presente estudo foi comparar as intensidades do ponto de compensação respiratório (PCR), limiar anaeróbio de concentração fixa $\left(\mathrm{OBLA}_{3,5}\right)$ e limiar anaeróbio de lactato de aumento abrupto lactacidêmico $\left(\mathrm{LAn}_{\mathrm{LAC}}\right)$ determinadas em quatro diferentes ergômetros.

\section{PROCEDIMENTOS METODOLÓGICOS}

\section{Sujeitos}

Onze mesatenistas do sexo masculino $(19 \pm 1$ anos de idade, $70,8 \pm 3,9 \mathrm{~kg}$ de massa corporal e 174,3 $\pm 2,1 \mathrm{~cm}$ de estatura) de duas equipes de tênis de mesa do estado de São Paulo foram voluntários do estudo. Esses atletas realizavam treinamento regular, sistemático e periodizado há, pelo menos, quatro anos e participavam regularmente de competições de nível estadual e nacional, sendo uma amostra tecnicamente representativa da população de mesatenistas. Os participantes foram informados dos riscos e benefícios do experimento e assinaram um termo de consentimento livre e esclarecido antes da realização dos testes. Para atletas menores de 18 anos, o termo de consentimento foi assinado por um responsável legal. Os procedimentos metodológicos foram aprovados pelo Comitê de Ética em Pesquisa do Instituto de Biociências da Universidade Estadual Paulista (UNESP), Campus Rio Claro (Processo 2982).

\section{PROCEDIMENTOS EXPERIMENTAIS}

Todos os procedimentos do estudo foram aplicados em um período de duas semanas, que consistiu em quatro sessões de avaliações (quatro testes incrementais máximos), com intervalo mínimo de 48 h entre cada sessão. Os testes incrementais foram realizados no cicloergômetro, ergômetro de braço, esteira rolante e em teste específico para o tênis de mesa e aplicados de modo aleatório.

Os testes incrementais consistiram em exercícios com estágios de esforços com duração de 3 min realizados até a exaustão voluntária do 
participante. Após cada estágio de esforço, foi padronizada uma pausa de 20 s para coleta de $25 \mathrm{~mL}$ de sangue do lóbulo da orelha para determinação da lactacidemia. O consumo de oxigênio $\left(\dot{V} \mathrm{O}_{2}\right)$, produção de dióxido de carbono $\left(\dot{V} \mathrm{CO}_{2}\right)$ e a ventilação pulmonar $\left(\dot{V}_{\mathrm{E}}\right)$ foram mensurados em todos os testes incrementais, por meio da análise de amostras gasosas mensuradas a cada ciclo de três respirações, por um sistema portátil de mensuração metabólica MedGraphics VO2000 (Medical Graphics Corp., St. Paul, MN, EUA). O equipamento foi calibrado imediatamente antes de cada avaliação seguindo as recomendações do fabricante.

A frequência cardíaca também foi mensurada continuamente através de um sensor T31 Polar (Polar, Finlândia) interconectado ao analisador metabólico MedGraphics VO2000. Para análise da lactacidemia ([La]), amostras de sangue também foram coletadas aos 3, 5 e 7 min após o término dos testes incrementais. As amostras sanguíneas coletadas foram armazenadas congeladas em $50 \mathrm{~mL}$ de fluoreto de sódio a $1 \%$ e posteriormente, analisadas em lactímetro eletroquímico YSI 1500 SPORT (YSI, Yellow Springs, OH, EUA).

\section{Testes incrementais}

Os testes incrementais aplicados no cicloergômetro e no ergômetro de braço foram realizados em cicloergômetro de frenagem mecânica Monark 894E (Monark, Suécia). Para a aplicação do teste no ergômetro de braço, foi construído um suporte metálico para o cicloergômetro Monark 894E (Monark, Suécia), que continha também assento e encosto traseiro almofadado. $\mathrm{O}$ assento foi ajustado individualmente para cada sujeito, com o participante fixado pelo tórax, no encosto traseiro, por uma fita de velcro para não possibilitar movimentos auxiliares de tronco. As intensidades iniciais corresponderam a $100 \mathrm{~W}$ e $30 \mathrm{~W}$ no cicloergômetro e no ergômetro de braço, respectivamente, e foram incrementadas em $15 \mathrm{~W}$ após cada estágio de esforço, com cadência fixa em $60 \mathrm{rpm}$. O teste incremental em esteira foi aplicado em um equipamento motorizado da marca Inbramed ATL (Inbrasport, Porto Alegre, Brasil), com velocidade inicial de $8 \mathrm{~km}^{-1}$ e foi aumentada em 1,5 $\mathrm{km} \cdot \mathrm{h}^{-1}$ após cada estágio de esforço, com inclinação fixa em $1 \%$.

O teste específico foi realizado na mesa de tênis de mesa, com os participantes rebatendo as bolas disparadas por um lançador de bolas mecânico roboPro plus Tibhar (Tibhar, Alemanha), em ataques regulares e constantes apenas de forehand ${ }^{9,14}$. A amplitude de lançamento de bola foi ajustada em sua regulagem máxima (unidade arbitrária 5 do controle do equipamento), possibilitando o lançamento da bola em dois locais diferentes da mesa $(\approx 30$ a $40 \mathrm{~cm}$ lateralmente a linha central da mesa) e o quique da bola ajustado para ocorrer entre $50 \mathrm{a} 60 \mathrm{~cm}$ à frente da rede, para simular a resposta de um adversário no jogo ${ }^{9,14}$. A velocidade de lançamento de bolas foi mantida constante durante todo o teste e correspondeu à unidade arbitrária 4 (aproximadamente $35 \mathrm{~km} \cdot \mathrm{h}^{-1}$ ). $\mathrm{O}$ controle da intensidade de exercício foi realizado por ajustes na frequência de lançamento de bolas $(f)$, que foi regulada para apresentar uma sensibilidade de 1 bola $\min ^{-1}$ a cada alteração na unidade arbitrária do equipamento. Após essa padronização, o teste em ergômetro específico 
foi realizado com intensidade inicial de disparo de bola de 30 bolas $\mathrm{min}^{-1}$ e aumentada em 4 bolas min $^{-1}$ após cada estágio de esforço, sendo o teste realizado até a exaustão voluntária do participante.

\section{Determinação da intensidade correspondente à capacidade aeróbia}

A intensidade de limiar anaeróbio de lactato $\left(\mathrm{LAn}_{\mathrm{LAC}}\right)$ foi correspondente ao segundo aumento abrupto da concentração lactacidêmica e foi identificado pelo método de regressão linear bi-segmentada ${ }^{14,21}$; a intensidade do PCR correspondeu ao ponto de aumento de ambos equivalentes ventilatórios de $\mathrm{O}_{2}\left(\dot{V}_{\mathrm{E}} / \dot{V} C \mathrm{O}_{2}\right)$ e $\mathrm{CO}_{2}\left(\dot{V} \mathrm{CO}_{2} / \dot{V}_{\mathrm{E}}\right)^{13-15}$ e; a intensidade de limiar anaeróbio de concentração fixa $\left(\mathrm{OBLA}_{3,5}\right)$ foi aquela correspondente a concentração de lactato de $3,5 \mathrm{mmol} \cdot \mathrm{L}^{-1}$.

\section{Análise estatística}

Os resultados estão apresentados em média erro padrão da média. Foi utilizado o teste de Shapiro Wilk para a análise da normalidade das variáveis, possibilitando a aplicação da estatística paramétrica. O teste de análise de variância (ANOVA) one way para medidas repetidas foi utilizado para comparação entre as intensidades de capacidade aeróbia estimada por diferentes métodos interergômetro. A ANOVA two way para medidas repetidas foi o procedimento adotado para análise de possíveis diferenças significativas entre as variáveis dependentes obtidas nos testes incrementais inter e intraergômetros. Em adição a análise de medidas repetidas, a esfericidade foi verificada pelo teste de Mauchly e caso violado. Em caso de violação da esfericidade, foi utilizada a correção Epsilon de Greenhouse Geisser. A análise foi complementada pela comparação multiteste de Bonferroni. O teste de correlação produto-momento de Pearson foi utilizado para analisar a associação entre as variáveis em todos os modos de exercício e entre valores de capacidade aeróbia estimada por diferences procedimentos. Em todos os casos, foi adotado um nível de significância de $P<0,05$.

\section{RESULTADOS}

Nos testes aplicados em diferentes modos de exercícios, as intensidades máximas obtidas nos testes incrementais foram $180,4 \pm 5,6 \mathrm{~W}$ no cicloergômetro, $86,8 \pm 6,1 \mathrm{~W}$ no ergômetro de braço, $13,5 \pm 0,4 \mathrm{~km} \cdot \mathrm{h}^{-1}$ na esteira e $47,3 \pm 3,14$ bolas min $^{-1}$ no teste específico para o tênis de mesa.

Tabela 1. Intensidades correspondentes à capacidade aeróbia estimada pelo ponto de compensação respiratório $(P C R)$, limiar anaeróbio de lactato $\left(\mathrm{LAn}_{\mathrm{ACC}}\right)$ e limiar anaeróbio de concentração fixa de lactato $\left(0 B A_{3.5}\right)$ determinadas em testes incrementais realizados no cicloergômetro, ergômetro de braço, esteira e em teste específico para o tênis de mesa.

\begin{tabular}{llll}
\hline & $\mathrm{PCR}$ & $\mathrm{LAn}_{\mathrm{LAC}}$ & $\mathrm{OBLA}_{3,5}$ \\
\hline Cicloergômetro $(\mathrm{W})$ & $149,3 \pm 4,9^{*}$ & $149,3 \pm 4,7^{*}$ & $131,9 \pm 6,6$ \\
\hline Ergômetro de braço $(\mathrm{W})$ & $63,4 \pm 4,8$ & $66,9 \pm 4,5$ & $64,5 \pm 6,1$ \\
\hline Esteira $\left(\mathrm{km} \cdot \mathrm{h}^{-1}\right)$ & $11,4 \pm 0,4$ & $11,3 \pm 0,3$ & $11,1 \pm 0,3$ \\
\hline Teste específico (bolas: $\left.\mathrm{min}^{-1}\right)$ & $40,5 \pm 1,8$ & $42,6 \pm 3,6$ & $42,8 \pm 5,6$ \\
\hline
\end{tabular}

${ }^{*} p<0,05$ em relação ao $0 \mathrm{BLA}_{3,5}$ 
Não foram verificadas diferenças significativas $(P>0,05)$ intraergômetro entre as intensidades correspondentes ao PCR, OBLA ${ }_{3,5}$ e $\mathrm{LAn}_{\mathrm{LAC}}$ no teste específico, no ergômetro de braço e na esteira. Apenas no cicloergômetro foi observado valor de $\mathrm{OBLA}_{3,5}$ significativamente inferior ao PCR e LAnLAC (Tabela 1). Correlações significativas foram verificadas entre o PCR e OBLA ${ }_{3,5}$ no teste específico e no ergômetro de braço; entre o PCR e o $\mathrm{LAn}_{\mathrm{LAC}}$ no teste específico e; entre o OBLA ${ }_{3,5}$ e o LAn ${ }_{\mathrm{LAC}}$ no teste específico e esteira (Tabela 2).

$\mathrm{Na}$ tabela 3, são apresentados o consumo de oxigênio $\left(\dot{V} \mathrm{~V}_{2}\right)$, a intensidade correspondente a capacidade aeróbia relativa à intensidade máxima obtida no teste incremental, frequência cardíaca (FC), percepção subjetiva de esforço (PSE) e lactato sanguíneo ([La]) correspondentes às intensidades

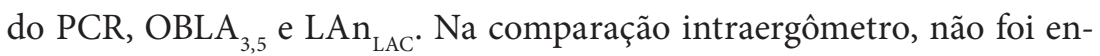
contrada diferença significativa $(P>0,05)$ entre os parâmetros mensurados $\left(\mathrm{VO}_{2}\right.$, intensidade relativa à máxima, $\left.\mathrm{FC}, \mathrm{PSE} \mathrm{e}[\mathrm{La}]\right)$ correspondentes às intensidades do PCR, $\mathrm{LAn}_{\mathrm{LAC}}$ e OBLA ${ }_{3,5}$. No entanto, foram verificadas diferenças significativas $(P<0,05)$ entre esses parâmetros para o mesmo procedimento de determinação da capacidade aeróbia (PCR, LAn $_{\text {LAC }}$ ou $\mathrm{OBLA}_{3,5}$ ) entre os ergômetros, com exceção da PSE que não apresentou diferença.

$\mathrm{O} \mathrm{VO}_{2}$ correspondente à intensidade de capacidade aeróbia obtida por meio dos diferentes métodos de análise (PCR, $\mathrm{LAn}_{\mathrm{LAC}_{\mathrm{C}}}$ e OBLA ${ }_{3,5}$ ) foram inferiores no ergômetro de braço em relação aos outros modos de exercício $(P<0,05)$, enquanto que apenas no PCR o valor obtido no cicloergômetro foi significativamente inferior ao obtido no teste específico. Para a intensidade relativa à máxima não foram verificadas diferenças significativas entre os modos de exercício para o PCR e o LAn ${ }_{\mathrm{LAC}}$, mas no $\mathrm{OBLA}_{3,5}$ o resultado no teste específico foi similar à esteira e superior ao cicloergômetro e ergômetro de braço, enquanto que o valor da esteira foi superior $(P<0,05)$ ao ergômetro de braço. Para a FC, os valores verificados no ergômetro de braço foi, de modo geral, estatisticamente inferior aos outros ergômetros (exceto no LAn $\mathrm{LAC}_{\mathrm{LC}}$ e OBLA ${ }_{3,5}$ em relação ao cicloergômetro), porém, a FC correspondente ao $\mathrm{OBLA}_{3,5}$, no cicloergômetro, foi inferior a verificada na esteira e no teste específico. Finalmente, para a concentração de lactato, apenas o valor obtido no PCR no cicloergômetro foi superior ao observado no teste específico. Esses resultados estão apresentados na tabela 3 .

Tabela 2. Coeficientes de correlação de Pearson $(r)$ entre o ponto de compensação respiratório $(P C R)$, limiar anaeróbio de lactato ( $\left(\mathrm{L} \mathrm{n}_{\mathrm{LAC}}\right)$ e limiar anaeróbio de concentração fixa de lactato $\left(0 \mathrm{BLA} \mathrm{A}_{5}\right)$ dentro dos testes incrementais realizados no cicloergômetro, ergômetro de braço, esteira e teste específico para o tênis de mesa.

\begin{tabular}{lcccc}
\hline & Cicloergômetro & Ergômetro de Braço & Esteira & Teste específico \\
\hline PCR vs OBLA & $r=0,13$ & $r=0,78^{*}$ & $r=0,11$ & $r=0,89^{*}$ \\
PCR vs LAn & $r=0,37$ & $r=0,36$ & $r=0,47$ & $r=0,83^{*}$ \\
OBLA $_{3,5}$ vs LAn $_{\text {LAC }}$ & $r=0,27$ & $r=0,36$ & $r=0,76^{*}$ & $r=0,95^{*}$ \\
\hline
\end{tabular}

${ }^{*} p<0,05$ 
Tabela 3. Valores do consumo de oxigênio $\left(\dot{V} \mathrm{O}_{2}\right)$, intensidade correspondente à capacidade aeróbia relativa à máxima, frequência cardíaca (FC), percepção subjetiva de esforço (PSE) e concentração de lactato ([La]) correspondentes ao PCR, OBLA ${ }_{3,5}$ e LAn ${ }_{\mathrm{LAC}}$ obtidos no teste específico, cicloergômetro, ergômetro de braço e esteira.

\begin{tabular}{|c|c|c|c|c|}
\hline \multicolumn{5}{|c|}{ Ergômetros } \\
\hline & Cicloergômetro & Ergômetro de braço & Esteira & Teste específico \\
\hline \multicolumn{5}{|c|}{$\dot{V} O_{2}\left(\mathrm{ml}^{\prime} \mathrm{kg}^{-1} \cdot \mathrm{min}^{-1}\right)$} \\
\hline PCR & $33,8 \pm 1,5^{\mathrm{a}}$ & $18,0 \pm 1,1^{\mathrm{a}, \mathrm{b}}$ & $37,7 \pm 1,7^{c}$ & $35,2 \pm 2,2$ \\
\hline $\operatorname{LAn}_{\mathrm{LAC}}$ & $33,5 \pm 1,3$ & $20,5 \pm 1,9^{a, b}$ & $37,8 \pm 1,2^{c}$ & $36,6 \pm 2,4$ \\
\hline $\mathrm{OBLA}_{3,5}$ & $29,8 \pm 1,9$ & $18,2 \pm 1,1^{\mathrm{a}, \mathrm{b}}$ & $36,3 \pm 1,0^{c}$ & $37,2 \pm 1,7$ \\
\hline \multicolumn{5}{|c|}{ Intensidade relativa à máxima (\%) } \\
\hline PCR & $83,0 \pm 2,4$ & $73,5 \pm 3,6$ & $84,4 \pm 3,7$ & $87,0 \pm 3,0$ \\
\hline $\operatorname{LAn}_{\mathrm{LAC}}$ & $82,8 \pm 3,9$ & $78,0 \pm 3,8$ & $84,6 \pm 2,2$ & $89,5 \pm 4,0$ \\
\hline $\mathrm{OBLA}_{3,5}$ & $73,6 \pm 2,9^{a}$ & $71,5 \pm 3,8^{\mathrm{a}}$ & $82,9 \pm 2,1^{c}$ & $90,9 \pm 3,1$ \\
\hline \multicolumn{5}{|c|}{ Frequência cardíaca (bpm) } \\
\hline PCR & $169,3 \pm 3,7$ & $130,7 \pm 3,1^{a, b}$ & $178,9 \pm 5,0^{c}$ & $180,8 \pm 5,7$ \\
\hline $\operatorname{LAn}_{\text {LAC }}$ & $168,1 \pm 3,0$ & $140,5 \pm 9,4^{\mathrm{a}}$ & $177,2 \pm 4,1^{c}$ & $179,2 \pm 6,0$ \\
\hline $\mathrm{OBLA}_{3,5}$ & $157,2 \pm 7,1^{\mathrm{a}}$ & $132,7 \pm 4,7^{a}$ & $166,0 \pm 10,2^{b, c}$ & $182,8 \pm 7,2$ \\
\hline \multicolumn{5}{|c|}{ Percepção Subjetiva de Esforço. } \\
\hline PCR & $15,1 \pm 0,7$ & $14,4 \pm 0,8$ & $14,5 \pm 1,0$ & $13,3 \pm 1,1$ \\
\hline $\operatorname{LAn}_{\mathrm{LAC}}$ & $14,8 \pm 0,8$ & $15,2 \pm 0,7$ & $14,8 \pm 0,7$ & $1,8 \pm 0,6$ \\
\hline $\mathrm{OBLA}_{3,5}$ & $13,0 \pm 0,9$ & $14,1 \pm 0,6$ & $14,48 \pm 0,6$ & $16,6 \pm 1,2$ \\
\hline \multicolumn{5}{|c|}{$[\mathrm{La}]\left(\mathrm{mmol} \cdot \mathrm{L}^{-1}\right)$} \\
\hline PCR & $4,6 \pm 0,5^{a}$ & $3,9 \pm 0,3$ & $3,7 \pm 0,4$ & $2,8 \pm 0,4$ \\
\hline $\operatorname{LAn}_{\mathrm{LAC}}$ & $3,9 \pm 0,3$ & $4,1 \pm 0,5$ & $3,3 \pm 0,3$ & $2,8 \pm 0,3$ \\
\hline
\end{tabular}

VO - - consumo de oxigênio; [La] - concentração de lactato; PCR - Ponto de compensação respiratório; LAnLAC - Limiar anaeróbio de lactato por regressão linear bi-segmentada; OBLA3,5 - Limiar anaeróbio por concentração fixa de lactate de 3,5 mmol. $\mathrm{L}^{-1}$. Diferença significativa $(p<0,05)$ em relação: ateste específico; 'bicloergômetro; 'ergômetro de braço.

\section{DISCUSSÃO}

Os principais achados do estudo foram as diversas similaridades nos valores de intensidades entre PCR, $\mathrm{LAn}_{\mathrm{LAC}}$ e OBLA ${ }_{3,5}$ e as significativas correlações entre eles, principalmente, no teste específico. No entanto, essas significativas correlações foram discretamente observadas nos outros ergômetros, sinalizando uma influência do modo de exercício na avaliação.

Essa similaridade entre os procedimentos de mensuração da capacidade

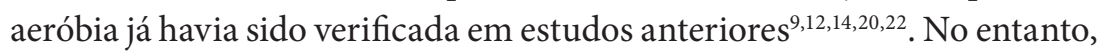
esse fenômeno fisiológico (capacidade aeróbia) tem sido classificado com terminologias distintas, como limiar anaeróbio, limiar de lactato, ponto de compensação respiratório, limiar anaeróbio individual e outros, o que gera certa confusão da literatura. Neste contexto, Faude et al. ${ }^{20}$ e Meyer et al. ${ }^{12}$ realizaram uma revisão de literatura dos últimos 30 anos de mensuração desses fenômenos fisiológicos. Esses autores sugeriram utilizar o termo limiar aeróbio de lactato para caracterizar o primeiro aumento do lactato acima da linha base, que é considerado como a mínima intensidade de exercício para ocorrer alguma alteração fisiológica no metabolismo aeróbio ${ }^{23}$; limiar anaeróbio de lactato para caracterizar a intensidade de capacidade aeróbia quando determinada, utilizando amostras lactacidêmicas; limiar 
anaeróbio de trocas gasosas para caracterizar a intensidade de capacidade aeróbia, quando determinada, utilizando trocas gasosas.

Embora esses procedimentos procurem mensurar o mesmo fenômeno fisiológico, eles podem sofrer algumas alterações, como a diferença significativa verificada no presente estudo entre a intensidade de $\mathrm{OBLA}_{3,5} \mathrm{com} \mathrm{o}$

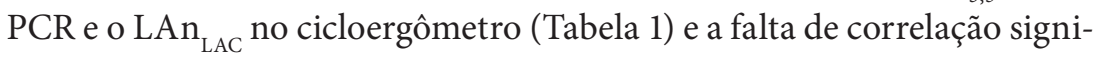
ficativa entre esses procedimentos no cicloergômetros e outros ergômetros (Tabela 2). Esse resultado sinaliza que os procedimentos de determinação da capacidade aeróbia sofrem influência do modo de exercício, e parecem ser menos influenciado quando o ergômetro selecionado é o mais próximo possível dos movimentos realizados pelo individuo na sua rotina, como ergômetro específico em caso de treinamento ou utilização da esteira devido ao andar ser o principal meio de locomoção do homem.

No entanto, a utilização de um procedimento que estima a intensidade da capacidade aeróbia por concentração fixa de lactato, como o caso do OBLA $_{3,5}$, deve ser utilizada com cautela, principalmente, levando em consideração o ergômetro utilizado ${ }^{17}$.Essa preocupação é necessária, pois a concentração de lactato correspondente à intensidade de capacidade aeróbia não é fixa ${ }^{17}$, e a adoção de um valor fixo pode resultar em erros na estimativa da capacidade aeróbia. A concentração de lactato na intensidade de capacidade aeróbia pode ser influenciada pelo tipo de exercício devido a massa muscular ativa ${ }^{17}$, assim como pelo tempo de estágio de exercício ${ }^{1,11}$, como verificado em nosso estudo entre OBLA ${ }_{3,5}$ com PCR e $\mathrm{LAn}_{\mathrm{LAC}}$ no cicloergômetro (Tabela 1).

$\mathrm{Na}$ análise entre os ergômetros utilizados no presente estudo, com o mesmo método de determinação da capacidade aeróbia, foram verificadas algumas diferenças significativas. De modo geral, os valores obtidos no ergômetro de braço foram significativamente inferiores aos observados nos outros ergômetros (Tabela 3). Essas diferenças podem possuir duas explicações: Primeiro, a influência da massa muscular envolvida no exercício. Dos quatro testes aplicados, o ergômetro de braço é o que utiliza a menor massa muscular durante o exercício (somente membro superior), que resultaria em menor sobrecarga orgânica e, consequentemente, menores respostas do $\dot{\mathrm{VO}}_{2}$ e da FC. No entanto, essa menor massa muscular ativa não reflete em menor valor de PSE e da resposta lactacidêmica, pois quanto maior a massa muscular ativa, maior seria a remoção do lactato sanguíneo na mesma intensidade relativa de exercício ${ }^{17}$; Segundo, existe uma diferença na "qualidade" da sobrecarga empregada nesses diferentes ergômetros. A sobrecarga do exercício pode ser efetuada tanto por aumento da potência interna, que é caracterizada pelas mudanças energéticas para movimentar os segmentos corporais ${ }^{24,25}$, quanto da potência externa, que corresponde à energia gasta para vencer uma resistência externa ${ }^{25}$. Assim, pode-se mencionar que a sobrecarga no cicloergômetro foi realizada com o aumento da potência externa, enquanto que a sobrecarga aplicada na esteira rolante e no teste específico foi realizada pelo aumento da potência interna, pois o aumento da velocidade de corrida e do lançamento de bolas implica 
necessidade de movimentar os segmentos corporais em maior velocidade. Essa diferença do tipo de sobrecarga imposta durante o exercício também explicaria os maiores valores de $\dot{V} \mathrm{O}_{2}$ e outros parâmetros na esteira e no teste específico, pois o aumento da potência interna resulta em maior gasto energético em relação ao aumento da potência externa para a mesma intensidade de exercício ${ }^{24,25}$

Embora a sensibilidade dos parâmetros determinados aos efeitos do treinamento não tenham sido investigados, não podemos deixar de mencionar a especificidade da avaliação, pois esses atletas eram treinados no tênis de mesa. Assim, como as adaptações fisiológicas ocorridas com o treinamento são específicas ao modo de exercício treinado e não são totalmente transferíveis a outros modos de exercício ${ }^{16,18}$, essas adaptações podem ter influenciado resultados um pouco inferiores no teste especifico devido a uma maior economia de movimento para a mesma intensidade de exercício em comparação a grupos musculares não treinados. Essa especificidade do treinamento e do teste possivelmente resultou no baixo valor de lactato observado no PCR $\left(2,8 \pm 0,4 \mathrm{mmol}^{-1}\right)$ e no $\operatorname{LAn}_{\mathrm{LAC}}\left(2,8 \pm 0,3 \mathrm{mmol} \cdot \mathrm{L}^{-1}\right)$ no teste específico e os elevados coeficientes de correlação encontrados.Esses resultados da correlação apresentados (Tabela 2) demonstram que, apesar dos protocolos utilizados para mensuração da capacidade aeróbia parecerem representar o mesmo fenômeno fisiológico, esses resultados podem ser modificados quando é selecionado um ergômetro não específico ao treinado pelo sujeito.

No entanto, uma limitação do estudo foi não ter sido aplicado o teste de MFEL, que é considerado como o procedimento padrão ouro na avaliação da capacidade aeróbia. Contudo, a utilização desse procedimento no estudo resultadria em um aumento muito grande no número de avaliações. Assim, nós procuramos utilizar todos os procedimentos aceitos que estimam a intensidade de MFEL por meio de teste incremental, tanto utilizando respostas respiratórias e ventilatócias como o caso do PCR, quanto respostas lactacidemicas, verificando o aumento abrupto da lactacidemia utilizando procedimento individual $\left(\mathrm{LAn}_{\mathrm{LAC}}\right)$ e de concentração fixa $\left(\mathrm{OBLA}_{3,5}\right)$. Além disso, a utilização de um número de participantes maior poderia auxíliar na obtenção de resultados muito mais consistentes.

Baseados nos achos do presente estudo, podemos sugerir que na determinação da capacidade aeróbia em um teste específico, tanto o PCR, LAn $n_{\text {LAC }}$ e OBLA ${ }_{3,5}$ podem ser utilizado. No entanto, quando o ergômetro utilizado não respeitar o modo de exercício mais realizado pelo indivíduo ou o modo de exercício treinado, o procedimento de avaliação da capacidade aeróbio em teste incremental deve ser selecionado com cautela. Assim, no contexto prática da ciência do esporte, não devemos selecionar um ergômetro para avaliação e o procedimento simplesmente pela disponibilidade de equipamento, como o uso do cicloergômetro e esteira, assim como análise da resposta lactacidêmica por concentração fixa, pois ambos fatores podem afetar a determinação da capacidade aeróbia.

Pelo fato da intensidade de capacidade aeróbia determinada pelo ponto de compensação respiratório, limiar anaeróbio de lactato de $3,5 \mathrm{mmol} \cdot \mathrm{L}^{-1}$ 
e limiar anaeróbio de lactato não terem sido significativamente diferentes e terem sido fortemente correlacionados, principalmente, no teste específico, é sugerido que: 1) a intensidade de capacidade aeróbia parece ser protocolo dependente em relação ao modo de exercício executado, com excessão ao teste específico a modalidade treinada, no qual em ergômetros não específicos ao treinado pelo avaliado, correlações fortes e significativas são modestamente observadas e; 2) o modo de exercício que solicita maior massa muscular, como o caso da esteira e do teste específíco, são os que resultam em maiores respostas fisiológicas na capacidade aeróbia; 3) a seleção do ergômetro deve ser realizada, respeitando a específicidade do treinamento do atleta ou o modo principal de deslocamento que ele possui.

\section{REFERÊNCIAS BIBLIOGRÁFICAS}

1. Heck H, Mader A, Hess G, Mücke S, Muller R, Hollmann W. Justification of the 4-mmol/l lactate threshold. Int J Sports Med 1985;6:117-30.

2. Beneke R. Methodological aspects of maximal lactate steady state-implications for performance testing. Eur J Appl Physiol 2003;89:95-9.

3. Zagatto AM, Papoti M, Gobatto CA. Validity of critical frequency test for measuring table tennis aerobic endurance through specific protocol. J Sports Sci Med 2008;7:461-6.

4. Sotero RC, Cunha VNC, Madrid B, Sales MM, Moreira SR, Simões HG. Identificação do lactato mínimo de corredores adolescentes em teste de pista de três estágios incrementais. Rev Bras Med Esporte 2011;17:119-22.

5. Baron B, Noakes TD, Dekerle J, Moullan F, Robin S, Matran R, et al. Why does exercise terminate at the maximal lactate steady state intensity? Br J Sports Med 2008;42:528-33.

6. Billat LV. Use of blood lactate measurements for prediction of exercise performance and for control of training. Recommendations for long-distance running. Sports Med 1996;22:157-75.

7. Coyle EF, Coggan AR, Hopper MR, Walters TJ. Determinants of endurance in well-trained cyclists. J. Appl Physiol 1988;64:2622-30.

8. Secher NH. Physiological and biomechanical aspects of rowing - implications for training. Sports Med 1993;15:24-42.

9. Morel EA, Zagatto AM. Adaptação dos testes de lactato mínimo, potência crítica e limiar anaeróbio para avaliação da transição aeróbia-anaeróbia em protocolo específico para o tênis de mesa. Rev Bras Med Esporte 2008;14:518-22.

10. Zagatto AM, Papoti M, Caputo, F, Mendes OC, Denadai, BS, Baldissera V, et al. Comparação entre a utilização de saliva e sangue para determinação do lactato mínimo em cicloergômetro e ergômetro de braço em mesa-tenistas. Rev Bras Med Esporte 2004;10:475-80.

11. Pereira RR, Papoti M, Zagatto AM, Gobatto CA. Validação de dois protocolos para determinação do limiar anaeróbio em natação. Motriz 2002;8:63-8.

12. Meyer T, Lucia A, Earnest CP, Kindermann W. A conceptual framework for performance diagnosis and training prescription from submaximal gas exchange parameters--theory and application. Int J Sports Med 2005; 26(Suppl 1):S38-S48.

13. Wasserman K, Whipp BJ, Koyl SN, Beaver WL. Anaerobic threshold and respiratory gas exchange during exercise. J Appl Physiol 1973;35:236-43.

14. Zagatto AM, Miranda M, Gobatto CA. Critical power concept adapted for the specific table tennis test: comparisons between exhaustion criteria, mathematical modeling, and correlation with gas exchange parameters. Int J Sports Med 2011;32:503-10 
15. Girard O, Chevalier R, Leveque F, Micallef JP, Millet GP. Specific incremental field test for aerobic fitness in tennis. Br J Sports Med 2006;40:791-6.

16. Roels B, Schmitt L, Libicz S, Bentley D, Richalet JP, Millet G. Specificity of VO2MAX and the ventilatory threshold in free swimming and cycle ergometry: comparison between triathletes and swimmers. Br J Sports Med 2005;39:965-8.

17. Beneke R, Von Duvillard, SP. Determination of maximal lactate steady state response in selected sports events. Med Sci Sports Exerc 1996;28:241-6.

18. Tordi N, Belli A, Mougin F, Rouillon JD, Gimenez M. Specific and transfer effects induced by arm or leg training. Int J Sports Med 2001;22:517-24.

19. Dekerle J, Baron B, Dupont L, Vanvelcenaher J, Pelayo P. Maximal lactate steady state, respiratory compensation threshold and critical power. Eur J Appl Physiol 2003;89:281-8.

20. Faude O, Kindermann W, Meyers T. Lactate threshold concepts. How valid are they? Sports Med 2009;39:469-90.

21. Matsumoto I, Araki H, Tsuda K, Odajima H, Nishima S, Higaki Y, Tanaka H, Tanaka M, Shindo M. Effects of swimming training on aerobic capacity and exercise induced bronchoconstriction in children with bronchial asthma. Thorax 1999;54:196-201.

22. MacIntosh BR, Esau S, Svedahl K. The lactate minimum test for cycling: estimation of the maximal lactate steady state. Can J Appl Physiol 2002;27:232-49

23. Kindermann W, Simon G, Keul J. The significance of the aerobic-anaerobic transition for the determination of work load intensities during endurance training. Eur J Appl Physiol Occup Physiol 1979;42:25-34.

24. McDaniels J, Durstine JL, Hand GA, Martin JC. Determinants od metabolic cost during submaximal cycling. J Appl Plysiol 2002;93:823-8.

25. Tokui M, Hirakoba K. Effect of internal power on muscular efficiency during cycling exercise. Eur J Appl Physio 2007;101:565-70.

\section{Endereço para correspondência}

Alessandro Moura Zagatto

Departamento de Educação Física. Faculdade de Ciências, Universidade Estadual Paulista "Júlio de Mesquita Filho" (UNESP).

Av. Eng. Luiz Edmundo Carrijo Coube, 14-01.

CEP 17033-360 - Bauru, SP, Brasil. E-mail:azagatto@yahoo.com.br 